hấp cấp tính. Tuy nhiên, ở bệnh nhân của chúng tôi giải thích bởi sự gia tăng ure có liên quan đến quá trình lọc máu chưa thực sự tốt gây các rối loạn trong đó có rối loạn tiết tuy ngoại tiết.Trong nghiên cứu này chúng tôi nhận thấy tăng creatinine máu liên quan độc lập với tăng amylase máu và giảm albumin độc lập liên quan với xuất hiện rối loạn dạ dày ruột. Tăng amylase máu là phổ biến ở bệnh nhân BTMT nói chung, bênh nhân TNT chu kỳ nói riêng. Ở bênh nhân BTMT giai đoạn cuối có nhiều yếu tố liên quan đến tăng nồng độ amylase máu trong đó có giảm mức lọc câu thận [6],[7]. Kết quả nghiên cứu của chúng tôi khẳng định creatinine một lân nữa giảm chức năng thận, không đào thải được amylase qua đường niệu là nguyên nhân chủ yếu gây tăng amylase máu.

\section{KẾT LUÂNN}

-Nông độ amylase huyết tương trung bình là $112(92,25$ - 140,75) U/L, có 77,5\% bệnh nhân tăng nồng độ.

- Nồng độ amylase tương quan thuận với nồng độ ure máu, $r=0,303, p<0,01$. Nồng độ creatinine lại là yếu tố độc lập liên quan đến tăng amylase huyết tương.

\section{TÀI LIÊU THAM KHẢO}

1. Nguyễn Hữu Dũng, Đỗ Gia Tuyển (2021).
Điều trị thay thế thận suy bằng thận nhân tạo chu kỳ. Bệnh học nội khoa thận tiết niệu. Nhà xuất bản Y hoc tâp2: 225-244.

2. Lê Viêtet Thắng (2019). Chẩn đoán và điêu trị môt số bệnh câu thận, khe ống thận. Cập nhật chẩn đoán, điều trị và dự phòng một số bệnh thận. Hoc viện Quân y: 83,86-98.

3. Chen YH, Yang WC, Wang FM, et al. (2011). Risk factors associated with elevated serum pancreatic amylase levels during hemodialysis. Hemodial Int.2011 Jan 12, [Epub ahead of print].

4. Jiang CF, Ng KW, Tan SW, et al. (2002).Serum level of amylase and lipase in various stages of chronic renal insufficiency. Zhonghua Yi Xue Za Zhi (Taipei). 65(2): 49-54.

5. Lee SY, Lee KT, Kang TW, et al. (2005). Pancreatic enzyme elevations in Korean chronic renal failure patients. Korean J Gastroenterol. 45(2): 125-9.

6. Pal A, Mandal L. (2018). Serum Amylase in Patients of Chronic Kidney Disease Stage Three to Stage Five. Birat Journal of Health Sciences, 3(2), 403-407.

7. Lê Quang Hải, Nguyễn Hữu Dũng, Nguyễn Thị Thu Hương và cộng sự (2017). Khảo sát nồng độ amylase huyết thanh ở bệnh nhân bệnh thận mạn tính giai đoạn cuối. Tạp chí Y Dược lâm sàng 108 , tâp 12 số $5:$ 36-41.

8. Pando E, Alberti $P$, Mata $R$, et al. (2021). Early Changes in Blood Urea Nitrogen (BUN) Can Predict Mortality in Acute Pancreatitis: Comparative Study between BISAP Score, APACHE-II, and Other Laboratory Markers-A Prospective Observational Study. Can J Gastroenterol Hepatol. eCollection.

\title{
NHẬN XÉT ĐĂC ĐIỂM TỔN THƯƠNG GIẢI PHẪU GÃY LIÊN MẤU CHUYỂN XƯƠ'NG ĐÙI TRÊN HİNH ẢNH CHỤP CẮT LỚP VI TÍNH
}

\section{TÓM TẮT}

Mục tiêu: Đánh giá chính xác tổn thương giải phẫu đóng vai trò quan trọng trong xây dựng kế hoạch điều trị phẫu thuật gãy liên mấu chuyển xương đùi. Đối tượng và phương pháp: Gồm 101 bệnh nhân gãy liên mấu chuyển xương đùi được phân lioại tổn thương giải phẫu dựa trên $X$ quang theo phân loại của $A O$ và phân loại theo Etsuo dựa trên hình ảnh $C T$ $3 D$. Tìm hiểu mức độ phù hợp của phân loại theo $A O$ dựa trên $X$ quang so với phân loại theo Etsuo dựa trên hình ảnh CLVT. Kết quả: Kết quả nghiên cứucho thấy gãy liên mấu chuyển xương đùi tồn tại 3 đường gãy chính: đường gãy ở phía trước gặp ở 101 trường hợp

\footnotetext{
*BV Đa khoa vưng Tây Nguyên

**Hoc viên Quân Y

Chịu trách nhiệm chính: Lê Tất Thắng

Email: phamdangninh103@gmail.com

Ngày nhận bài: 4/4/2021

Ngày phản biện khoa học: 1/5/2021

Ngày duyệt băi: $18 / 5 / 2021$
}

\section{Lê Tất Thắng*, Đặng Hoàng Anh**}

(100\%), đường gãy ở phía sau gặp ở 92 trường hợp $(91,09 \%)$ và đường gãy ở phía ngoài gặp ở 53 trường hợp (52,47\%). Phân loại theo Etsuo gồm: gãy 2 phân chiếm $19,80 \%$, gãy 3 phần chiếm $72,28 \%$ và gãy 4 phần chiếm 7,92\%. Gãy 3 phần loại chỏm - mấu chuyển lớn + mấu chuyển bé +thân xương chiếm tỷ lệ cao nhất $(41,10 \%)$. Trong 41 trường hợp gãy 2 phần trên $X$ quang qui ước, chụp CLVT dựng hình $3 \mathrm{D}$ phát hiện 21 trướng hợp gãy 3 phần. Kết quả nghiên cứu ghi nhận có sự phù hợp kém về phân loại theo số phân gãy giữa XQ và CLVT với $K=0,405$. Kết luận: Phân loại gãy liên mấu chuyển dựa trên phim $X$ quang có sự hạn chế về độ chính xác. Hình ảnh chụp CLVT có dựng hình $3 \mathrm{D}$ đã được chứng minhlà chính xác cao hơn do phát hiện đây đủ hơn về vị trí, hình thái các đường gãy và số lượng mảnh gãy

Ti̛ khóa: Cắt lớp vi tính, gãy liên mấu chuyển, $X$ quang.

\section{SUMMARY \\ EVALUATION OF CHARACTERISTICS OF ANATOMICAL INJURIES OF}




\section{INTERTROCHANTERIC FRACTURES BASED ON COMPUTED TOMOGRAPHY SCANS}

Aim: A precise preoperative evaluation of anatomy injuries of intertrochanteric fractures is crucial for surgical planning. Subjects ànd methods: including 101 patients with intertrochanteric fracture were classified anatomical lesions based on X-rays according to $\mathrm{AO}$ classification and Etsuo classified based on 3D CT images. The evaluation of concordance rate between the $\mathrm{AO}$ classification based on X-rays and the Etsuo classification base on 3D CT images. Results: The study results showed that there are 3 main fracture lines for intertrochanteric fracture : the anterio fracture line was in 101 cases $(100 \%)$, the posterio fracture line was in 92 cases $(91.09 \%)$, and the broken line outside wasin 53 cases (52.47\%). Classification according to Etsuo includes: 2-part fracture, 19,80\%, 3-part fracture $72.28 \%$ and 4-part fracture $7.92 \%$. bone accounts for the highest percentage $(41.10 \%)$. In 41 cases of 2-part fractures on conventional radiographs, on 3D CT revealed 21 cases of 3-part fractures. The study results showed that there is a lowconcordance rate between the $\mathrm{AO}$ base on X-rays and Etsuo base on with $\mathrm{K}=0.405$. Conclusion: Classification of intertrochanteric fracture based on X-ray films has limited accuracy. CT scans with $3 \mathrm{D}$ rendering were shown to be more accurate due to more complete detection of fracture locations, morphology and number of fragments.

Keywords: computed tomography (CT) intertrochanteric fracture, X-ray.

\section{I. ĐĂT VẤN ĐỀ}

Gãy vùng mấu chuyển xương đùi là môt tổn thương thường gặp và có xu hướng ngày càng tăng do sự gia tăng của tuổi thọ dân số. Các phân loại gãy liên mấu chuyển xương đùi dựa trên $X$ quang của Evans, Jensen và $A O$ đang được áp dụng phổ biến hiện nay.[1] Tuy nhiên các phân loại này trong nhiều trường hợp vẫn chưa chính xác và làm hạn chế việc xây dựng kế hoạch điều trị. Phương pháp chup cắt lớp vi tính cho phép mô tả chi tiếtvề số phần gãy, đặc biệt là đặc điểm đường gãy vùng mấu chuyển lớn vì thế đã có một số bảng phân loại mới dựa trên hình ảnh chụp cắt lớp vi tính có dựng hình $3 \mathrm{D}$ (CT 3D) được đề xuất [2],[3]. Phân loại theo Etsuo dựa trên cách phân chia đầu trên xương đùi theo 4 phần chính gồm chỏm xương đùi, mấu chuyển lớn, mấu chuyển bé và thân xương lần đầu tiên được Estsuo mô tả là một trong những cách phân loại có nhiều cải tiến về cách đánh giá tổn thương trong không gian 3 chiều [2]. Nhằm đánh giá chính xác đặc điểm tổn thương giải phẫu của các trường hợp gãy liên mấu chuyển xương đùi chúng tôi tiến hành nghiên cứu hình ảnh tổn thương trên phim chụp cắt lớp vi tính và phim chụp $X$ quang qui ước với 2 mục tiêu:
1. Khảo sát đặc điểm tôn thương giải phẫu của gãy đầu trên xương đùi trên phim chụp cắt lớp vi tính có dựng hinh $3 D$.

2. Đối chiếu mức độ chính xác giữa phân loại dựa trên phim chụp CLVT và phân loại theoXQ qui ước.

\section{II. ĐỐI TƯợNG VÀ PHƯƠNG PHÁP NGHIÊN CỨU}

2.1 Đối tượng nghiên cứu. Gồm 101 bệnh nhân gãy kín liên mấu chuyển xương đùi được điều trịtại Bệnh viện đa khoa vùng Tây Nguyển từ tháng $9 / 2015$ đến tháng $5 / 2020$.

Tiêu chuẩn lựa chọn: - BN gãy kín liên mấu chuyển xương đùi. Tuổi $\geq 18$.

- Có đầy đủ phim chụp $X$ quang qui ước và phim chụp cắt lớp vi tính.

Tiêu chuẩn loại trừ: Gãy xương bệnh lý.

2.2. Phương pháp nghiên cứu

- Mô tả cắt ngang.

- Đocc kết quả trên phim X quang và phim chụp cắt lớp vi tính về hình thái tổn thương đầu trên xương đùi: do nhóm BS chuyên khoa chẩn đoán hình ảnh có kinh nghiệm và nghiên cứu sinh thực hiện theo các nội dung nghiên cứu.

\subsection{Các chỉ tiêu nghiên cứu}

- Tuổi bệnh nhân, giới, nguyên nhân gãy xương: gồm tai nạn sinh hoạt, tai nạn giao thông và tai nạn lao động.

- Phần loại gãy xương theo $A O$ : gồm 3 loai $A 1, A 2, A 3$, và chín phân nhóm gồm: $A 1.1, A 1.2$, A1.3, A2.1, A2.2, A2.3, A3.1, A3.2, A.3.3.

- Mức độ loãng xương theo phân độ của Singh: gồm 6 độ

- Phân loại gãy liên mấu chuyển trên phim chụp CLVT theo các phần gãy: gồm có 4 phần gãy: phần cổ -chỏm, mấu chuyển lớn, mấu chuyển bé, thân xương.

- Vị trí các đường gãy trên phim chup CLVT:đường gãy phía trước (ở phía trước liển mấu chuyển), đường gãy phía sau (từ hố ngón tay xuống dưới), đường gãy bên ngoài (nơi có cơ mông lớn bám).

\section{0 .}

2.4. Xử lí số liệu bằng phân mềm SPSS

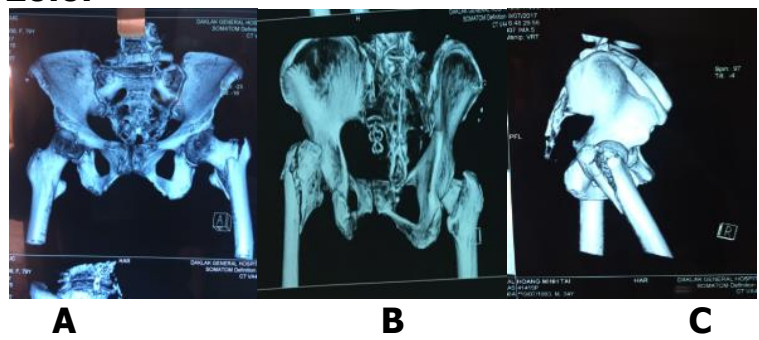

Hình 1. 1. Đường gãy phía trước $(A)$, phía sau (B) và thành ngoài (C). 


\section{KẾT QUẢ NGHIÊN CỨU}

\section{1. Đăc điểm đối tượng nghiên cứu}

- 101 bệnh nhân gồm 47 nam (46,53\%) và 54 nữ (53,47\%). Tuổi từ 23 đến 101 tuổi, trung bình là $71,75 \pm 15,57$ tuổi.

- Nguyên nhân do tai nạn sinh hoạt chiếm $82,18 \%$, trong đó phần lớn là do ngã. Có 5 trường hợp do tai nạn lao động ngã từ trên cao.

- Chất lượng xương theo chỉ số Singh: có 01 BN độ II, có 27 BN độ III (26,73\%), độ IV có 47BN $(46,53 \%)$.

3.2. Đặc điểm tổn thương gãy vùng mấu chuyển xương đùi trên CLVT.

Bảng 3.1. Vị trí đường gãy trên CLVT $(n=101)$

\begin{tabular}{|c|c|c|}
\hline Vị trí đường gãy & Số BN & $\mathbf{~ \% ~}$ \\
\hline Đường gãy trước & 101 & 100 \\
\hline Đường gãy sau & 92 & 91,09 \\
\hline Đường gãy bên ngoài & 53 & $52,47 \%$ \\
\hline
\end{tabular}
ảnh CT

*Phân loại gãy theo Etsuo dựa trên hình

Bảng 3.2. Phân loại theo số phần gãy ( $n=101$ ) \begin{tabular}{|c|c|c|}
\hline Phân loại theo Etsuo & Số BN & Tỷ lệ \% \\
\hline
\end{tabular}

\begin{tabular}{|c|c|c|}
\hline Gãy 2 phần & 20 & 19,80 \\
\hline Gãy 3 phần & 73 & 72,28 \\
\hline Gãy 4 phần & 8 & 7,92 \\
\hline
\end{tabular}

Bảng 3.3 Sự phân bố các mảnh gãy trong loại gãy 3 phần. ( $n=73$ ).

\begin{tabular}{|c|c|c|}
\hline $\begin{array}{c}\text { Các hình thái gãy LMC } 3 \\
\text { phần }\end{array}$ & $\begin{array}{c}\text { Số } \\
\text { BN }\end{array}$ & \% \\
\hline $\begin{array}{c}\text { Chỏm + MC lớn + (MC bé + } \\
\text { Thân xương) }\end{array}$ & 3 & 4,11 \\
\hline $\begin{array}{c}\text { Chỏm + (MC lớn + MC bé) } \\
\text { + Thân xương }\end{array}$ & 22 & 30,14 \\
\hline $\begin{array}{c}\text { (Chỏm- MC bé) + MC lớn + } \\
\text { Thân xương }\end{array}$ & 1 & 1.37 \\
\hline $\begin{array}{c}\text { Chỏm + MC bé + (MC lớn - } \\
\text { Thân xương) }\end{array}$ & 17 & 23,29 \\
\hline $\begin{array}{c}\text { (Chỏm -MC lớn) + MC bé + } \\
\text { Thân xương }\end{array}$ & 30 & 41,10 \\
\hline Cộng & $\mathbf{7 3}$ & $\mathbf{1 0 0 \%}$ \\
\hline
\end{tabular}

Kiếu gãy chỏm - mấu chuyến lớn + mấu chuyển bé +thân xương chiếm tỷ lệ cao nhất $(41,10 \%)$, gãy 3 phần kiểu có đường gãy chéo từ mấu chuyển lớn xuống mấu chuyển bé chiếm 22/73 TH.

Bảng 3.4. Mối liên quan giữa đường gãy bên ngoài và phân loại gãy theo Etsuo $(n=101)$.

\begin{tabular}{|c|c|c|c|}
\hline \multirow{2}{*}{ Thể gãy } & \multicolumn{2}{|c|}{ Đường gãy phía ngoài } & \multirow{2}{*}{ Tổng } \\
\hline & Khống có & Có & \\
\hline 2 phần & 15 & 5 & 20 \\
\hline 3 phần & 32 & 41 & 73 \\
\hline 4 phần & 1 & 7 & 8 \\
\hline Tống & 48 & 53 & 101 \\
\hline
\end{tabular}

ngoài $(52,47 \%)$ và gặp chủ yếu trong gãy 3 phần $(77,35 \%)(p=0,06)$.

Bảng 3.5. Phân loại theo $A O$ ở loại gãy 3 phần LMC. $(n=73)$

\begin{tabular}{|c|c|c|c|c|}
\hline \multirow{2}{*}{ Loại gãy 3 phân } & \multicolumn{3}{|c|}{$\begin{array}{c}\text { Phân loại A0 } \\
\text { trên Cív }\end{array}$} & \multirow{2}{*}{ Cộng } \\
\cline { 2 - 5 } & $\mathbf{A 1}$ & $\mathbf{A 2}$ & $\mathbf{A 3}$ & \\
\hline $\begin{array}{c}\text { Chỏm + MC lớn + (MC } \\
\text { bé + Thân xương) }\end{array}$ & 1 & 2 & 0 & 3 \\
\hline $\begin{array}{c}\text { Chỏm + (MC lớn + MC } \\
\text { bé) + Thân xương }\end{array}$ & 0 & 21 & 1 & 22 \\
\hline $\begin{array}{c}\text { (Chỏm- MC bé) + MC lớn } \\
\text { + Thân xương }\end{array}$ & 0 & 1 & 0 & 1 \\
\hline $\begin{array}{c}\text { Chỏm + MC bé + (MC } \\
\text { lớn - Thân xương) }\end{array}$ & 0 & 17 & 0 & 17 \\
\hline $\begin{array}{c}\text { (Chỏm -MC lớn) + MC bén } \\
\text { + Thân xương }\end{array}$ & 0 & 24 & 6 & 30 \\
\hline Tống & $\mathbf{1}$ & $\mathbf{6 5}$ & $\mathbf{7}$ & $\mathbf{7 3}$ \\
\hline Gãy LMC 3 phần (chỏm - mấu chuyến
\end{tabular}
lớn)+mấu chuyển bé + thân xương hay gặp ở loại gãy A2 hơn các loại gãy khác $(p=0,000)$.

Bảng 3.6. Liên quan giữa đường gãy phía sauvà phân loai theo Etsuo. $(n=101)$

\begin{tabular}{|c|c|c|c|}
\hline $\begin{array}{c}\text { Phân loại } \\
\text { Etsuo }\end{array}$ & \multicolumn{2}{|c|}{ Đường gãy phía sau } & \multirow{2}{*}{ Tổng } \\
\cline { 2 - 3 } & Không có & Có & \\
\hline 2 phần & 1 & 19 & 20 \\
\hline 3 phần & 8 & 65 & 73 \\
\hline 4 phần & 0 & 8 & 8 \\
\hline Tống & $\mathbf{9}$ & $\mathbf{9 2}$ & $\mathbf{1 0 1}$ \\
\hline
\end{tabular}

65/73 trường hợp gãy liên mấu chuyển có đường gãy phía sau trong, gãy 2 phần có 19 trường hợp gãy phía sau. Gãy 4 phần các trường hợp đều có đường gãy phía sau. với $p=0,464$

Bảng 3.7. Phân bố đường gãy phía sau trong các dạng gãy 3 phần theo Etsuo $(n=73)$

\begin{tabular}{|c|c|c|c|}
\hline \multirow{2}{*}{ Đường gãy 3 phân } & $\begin{array}{c}\text { Đường gãy phía } \\
\text { sau trong }\end{array}$ & \multirow{2}{*}{ Tổng } \\
\cline { 2 - 3 } & $\begin{array}{c}\text { Không } \\
\text { có }\end{array}$ & $\begin{array}{c}\text { Có } \\
\text { đường } \\
\text { gãy }\end{array}$ & \\
\hline $\begin{array}{c}\text { Chỏm + MC lớn+(MC } \\
\text { bé+Thân xương) }\end{array}$ & 3 & 0 & 3 \\
\hline $\begin{array}{c}\text { Chỏm + (MC lớn + } \\
\text { MC bé) + Thân xương }\end{array}$ & 22 & 0 & 22 \\
\hline $\begin{array}{c}\text { (Chỏm- MC bé) + MC } \\
\text { lớn + Thân xương }\end{array}$ & 1 & 0 & 1 \\
\hline $\begin{array}{c}\text { Chỏm + MC bé + (MC } \\
\text { lớn-Thân xương) }\end{array}$ & 3 & 14 & 17 \\
\hline $\begin{array}{c}\text { (Chóm -MC lớn+MC } \\
\text { bé+Thân xương }\end{array}$ & 6 & 24 & 30 \\
\hline Tống & 35 & 38 & 73 \\
\hline
\end{tabular}

Đường gãy sau trong hay gặp nhiều nhất trong loại gãy 3 phần (chỏm - mẩu chuyển lớn) + Mấu chuyển bé +thân xương.

3.3. Mức độ phù hợp giữa phân loại dựa 
trên phim $X$ quang và phim chụp CLVT

Bảng 3.8. So sánh giữa số phần gãy trên $X Q$ qui ước và $C L V T(n=101)$.

\begin{tabular}{|c|c|c|c|c|}
\hline \multirow{2}{*}{$\begin{array}{c}\text { Phim } \\
\text { CLVT }\end{array}$} & $\begin{array}{c}\mathbf{2} \\
\text { phần }\end{array}$ & $\begin{array}{c}\mathbf{3} \\
\text { phần }\end{array}$ & $\begin{array}{c}\mathbf{4} \\
\text { phần }\end{array}$ & $\begin{array}{c}\text { Số } \\
\text { BN }\end{array}$ \\
\hline 2 phần & 20 & 0 & 0 & 20 \\
\hline 3 phần & 21 & 49 & 3 & 73 \\
\hline 4 phần & 0 & 7 & 1 & 8 \\
\hline Số BN & 41 & 56 & 4 & 101 \\
\hline
\end{tabular}

Sự thay đối về số trường hợp gãy 3 phần tăng lên là do các mảnh gãy được phát hiện nhiều hơn trên phim CLVT ở diện cẳt mặt phẳng ngang. Trong số 41 trường hợp có gãy 2 phần trên $\mathrm{XQ}$ qui ước chỉ có 20 trường hợp được xác định chính xác có 2 phần trên phim CLVT. 21 trường hợp còn lại có 3 mảnh gãy được xác định trên phim CLVT. Kết quả nghiên cứu ghi nhận có sự phù hợp kém về phân loại theo số gãy giữa $X Q$ và $C L V T$ với $K=0,405$

Bảng 3.9. Sự phù hợp về chẩn đoán gãy thành ngoài giữa $X$ quang và $C L V T(n=101)$.

\begin{tabular}{|c|c|c|c|}
\hline $\begin{array}{c}\text { Đường gãy } \\
\text { ngoài trên } \\
\text { CLVT }\end{array}$ & \multicolumn{2}{|c|}{$\begin{array}{c}\text { Đường gãy thành } \\
\text { ngoài trên XQ }\end{array}$} & \multirow{2}{*}{ Tổng } \\
\cline { 2 - 3 } & Khồng & Có & \\
\hline Có & 33 & 20 & 53 \\
\hline Không có & 48 & 0 & 48 \\
\hline Tống & $\mathbf{8 1}$ & $\mathbf{2 0}$ & $\mathbf{1 0 1}$ \\
\hline
\end{tabular}

33 trường hợp không phát hiên tốn thương thành ngoài trên $X$ quang, nhưng chụp CLVT laai có tổn thương. Sự phù hợp về chẩn đoán tổn thương thành ngoài giữa XQ và CLVT là 20/53 trường hợp $(37,73 \%)$ và hệ số Kappa $=0,000$.

Bảng 3.10. Sự phù hợp giữa phân loại theo AO trên XQ và CLVT ( $n=101)$

\begin{tabular}{|c|c|c|c|c|c|c|c|c|c|c|c|}
\hline & \multicolumn{9}{|c|}{ Phân loại trên $X$ quang } & \multirow{2}{*}{ Tổng } \\
\hline & & $\mathrm{A} 1.1$ & A1.2 & $\mathrm{A} 1.3$ & $\mathrm{~A} 2.1$ & $\mathrm{~A} 2.2$ & $\mathrm{~A} 2.3$ & A3.1 & A3.2 & A3.3 & \\
\hline \multirow{6}{*}{$\begin{array}{c}\text { Phân } \\
\text { loại } \\
\text { trên } \\
\text { CLVT }\end{array}$} & $\mathrm{A} 1.1$ & 2 & 0 & 0 & 0 & 0 & 0 & 0 & 0 & 0 & 2 \\
\hline & $\mathrm{A} 1.2$ & 3 & 10 & 0 & 0 & 0 & 0 & 0 & 0 & 0 & 13 \\
\hline & $\mathrm{A} 1.3$ & 0 & 1 & $\mathbf{1}$ & 0 & 0 & 0 & 0 & 0 & 0 & 2 \\
\hline & $\mathrm{A} 2.1$ & 1 & 8 & 2 & 5 & 0 & 0 & 0 & 0 & 0 & 16 \\
\hline & $\mathrm{A} 2.2$ & 0 & 4 & 0 & 6 & 24 & 0 & 0 & 0 & 0 & 34 \\
\hline & A2.3 & 0 & 0 & 0 & 1 & 16 & 4 & 0 & 0 & 0 & 21 \\
\hline & A3.1 & 0 & 0 & 0 & 0 & 1 & 0 & 2 & 0 & 0 & 3 \\
\hline & A3.2 & 0 & 0 & 0 & 0 & 0 & 0 & 0 & 2 & 0 & 2 \\
\hline & A3.3 & 0 & 0 & 0 & 0 & 0 & 0 & 0 & 0 & 8 & 8 \\
\hline \multicolumn{2}{|c|}{ Tống } & 6 & 23 & 3 & 12 & 41 & 4 & 2 & 2 & 8 & 101 \\
\hline
\end{tabular}

Loại gãy A2.2 thay đổi nhiều nhất, có 16 trường hợp chẩn đoán gãy loại A2.2 trên $X$ quang qui ước, khi phân loại dựa trên hình ảnh CLVT chuyển sang loại $A 2.3$.

6 TH loại A2.1 trên XQ, trên phim chụp CLVT chuyển sang loại $A 2.2$ lý do XQ không phát hiện được các mảnh gãy mấu chuyển lớn nhưng trển phim CLVT thì phát hiện được. Sự phù hợp về chẩn đoán giữa XQ và CLVT là $58 / 101$ trường hợp $(57,42 \%)$ và hệ số $K=0,466$.

\section{BÀN LUÂ̂N}

4.1. Một số đặc điểm của nhóm nghiên cứu

4.1.1. Tuổi và giới tính. Gãy liên mấu chuyển là một chấn thương thường gặp xảy ra ở moi lứa tuổi, nhưng hay gặp nhất là ở người cao tuổi. Trong nghiên cứu của chúng tôi, tuổi trung bình của $B N$ là $71,75 \pm 15,57$, kết quả này cũng tương đương với một số nghiên cứu trong nước khác. Nhóm tuổi hay gặp nhất là 70-80 tuổi và sự khác biệt về số lượng $\mathrm{BN}$ ở các nhóm tuổi ý nghĩa thống kê với $p=0,006$. Tỉ lệ nam/nữ là $1 / 1,14$. Trong nghiên cứu này, theo phân loại của $A O$, gãy loại $A 2$ có độ tuổi trung bình cao nhất $74,11 \pm 14,13$, tuổi trung bình ở bệnh nhân nữ khá cao 76,44 $\pm 13,34$

Về mức độ loãng xương, trong nghiên cứu chứng tôi loãng xương độ 2 , độ 3 chủ yếu gặp ở bệnh nhân > 60 tuổi và gặp ở nữ nhiêu hơn. Loãng xương ở phụ nữ liên quan nhiều đến tình trạng mãn kinh vì vậy tỷ lệ loãng xương ở nữ thường cao hơn nam giới gấp nhiều lần. Nghiên cứu của chúng tôi tỷ lệ nữ có loãng xương độ 2,3,4 theo Singh cao hớn nam, sự khác biệt này có ý nghĩa thống kê với $p=0,01$.

4.1.2. Đặc điểm tổn thương giải phẫu. Chúng tôi đánh giá tổn thương giải phẫu trên phim cắt lớp vi tính theo cách phân loại của Etsuo, chia đầu trên xương đùi thành 4 phần chính là cổ chỏm, mấu chuyển lớn, mấu chuyển bé và thân xương đùi.

Kêt quả nghiên cứu của chúng tôi cho thấy gãy 2 phần chiếm 19,80\%, gãy 3 phần chiếm $72,28 \%$ và gãy 4 phần chiếm $7,92 \%$. Theo Keizo Wada và cộng sự [1], nghiên cứu $95 \mathrm{TH}$ có 31 $\mathrm{TH}(32,6 \%)$ gãy 2 mảnh và $64 \mathrm{TH}(67,4 \%)$ gãy nhiều hơn 3 mảnh. Không có sự khác biệt về độ 
tuổi giữa 2 nhóm $(p=0,509)$.

Chúng tôi nhận thấy gãy 3 phần gặp nhiều ở bệnh nhân loãng xương độ 2 và độ 3 và 4 . Kết quả nghiên cứu cho thấy không có sự liên quan giữa số $B N$ ở mỗi loại và chỉ số Singh $(p=$ 0,431),như vậy độ tuổi và mật độ xương không ảnh hưởng đển sự tạo nên các loại gãy.

Qua khảo sát trển hình ảnh CT3D chúng tôi nhận thấy gãy liên mấu chuyển xương đùi tồn tại 3 đường gãy chính: đường gãy trước gặp ở 101 trường hợp $(100 \%)$, đường gãy sau gặp ở 92 trường hợp $(91,09 \%)$ và đường gãy ngoài gặp ở 53 trường hợp $(52,47 \%)$. Điều này cũng phù hợp với các tác giả Futamura K.,Ryota Ito, Ming Li, El Sayed, đã báo cáo trước đó [4],[5], [6], như vậy khác với phim $X$ quang qui ước, khi khảo sát các phân loại gãy vùng mấu chuyển xương đùi, CLVT giúp chúng ta hiểu biết có tồn tại đường gãy bên ngoài, điều này sẽ rất hữu ích trong việc lựa chọn phương pháp điều trị.

Trong nghiên cứu chúng tôi thây có $41 / 73$ trường hợp gãy 3 phần có tổn thương thành ngoài trên hình ảnh cắt lớp vi tính. Đường gãy phía ngoài hay gặp nhất trong các gãy LMC 3 phần là kiểu gãy chỏm - mấu chuyển lớn + mấu chuyển bé+ thân xương.

Gãy có mảnh sau trong là tổn thương calcar nâng đỡ phía trong của vùng mấu chuyển xương đùi. Theo quan điểm trước đây, gãy phần sau và mảnh sau trong được xem là yếu tố quan trọng quyết định mức độ nghiêm trọng của loại gãy LMC. Khảo sát hình ảnh tổn thương của phần gãy sau trong trong nghiên cứu, chúng tôi nhận thấy gãy có mảnh sau trong chủ yếu xảy ra ở loại gãy 3 phần (38/73 trường hợp), Gãy mảnh sau trong thường hay găp ở loại gãy A2.2 (20/45 trường hợp), sự khác biệt này có ý nghĩa thống kê với $p=0,001$ (phép kiểm X2).

Khi nghiên cứu các kiểu gãy 3 phần chúng tôi nhận thấy kiểu gãy có mảnh chéo lớn từ mấu chuyển lớn xuống mấu chuyển bé (mảnh tách rời phía sau) là kiểu gãy gặp nhiều hơn so với các kiểu gãy 3 phần khác, sự khác biệt này có ý nghĩa thống kê $(p=0,001$, phép kiểm $x 2$, bảng), và trong 22 trường hợp gãy 3 phần mảnh chéo lớn từ mấu chuyển lớn xuống mấu chuyển bé có 18 trường hợp gãy có tổn thương thành ngoài, sự khác biệt này có ý nghĩa thống kê (với $\mathrm{p}=0,016$, phép kiểm $\times 2$ ). Chúng tôi cho đây là kiểu gãy chưa được nhận diện và báo cáo trong các hệ thống phân loại gãy LMC. Mảnh gãy này ở phía sau, đôi khi tách riêng ra khỏi khối mấu chuyển, khó phát hiện trên phim $X$ quang thường, dễ bị nhầm là vẫn còn liên tục với khối cổ mấu chuyển. Kết quả này chỉ ra rằng gãy 3 phần có mảnh chéo lớn từ mấu chuyển lớn xuống mấu chuyển bé thường có xu hướng bị chẩn đoán nhầm gãy vững nếu chỉ dựa theo $X$ quang qui ước. Theo Cho Y.C., để phân loại chính xác tổn thương trong gãy liên mấu chuyển xương đùi cần dựa vào hình ảnh $\mathrm{CT} 3 \mathrm{D}$ [7].

4.2. Đối chiếu mức độ chính xác tổn thương giải phấu đâu trên xương đùi trên phim XQ qui ước với phim cắt lớp vi tính. So sánh các phân gãy trên phim $X$ quang và trên phim CLVT, có thay đổi về số trường hợp gãy 3 mảnh tăng lên là do các mảnh gãy được phát hiện nhiều hơn trên phim CLVT ở diện cắt theo mặt phẳng ngang. Trong số 41 trường hợp có gãy 2 phần trên $X Q$ qui ước chỉ có 20 trường hợp được xác định chính xác là gãy 2 phần trên phim CLVT. 21 trường hợp còn lại trên phim CLVT xác định có gãy 3 mảnh. Nghiên cứu ghi nhận sự phù hợp kém củaphân loại theo số mảnh gãy dựa trên $X Q$ qui ước so với dựa trên CLVT với $\mathrm{K}=0,405$

Khi so sánh kêt quả phân loại $A O$ dựa trên phim $X$ quang và phim chụp CLVT, hầu hết các loại gãy đều có sự thay đổi của phân loại chẩn đoán, trong đó loại gãy A2.2 thay đổi nhiều nhất. Có 16 trường hợp chẩn đoán gãy loại $\mathrm{A} 2.2$ trên $X$ quang qui ước, khi phân loại theo hình ảnh CLVT chuyển sang loại $A 2.3$; có $6 \mathrm{TH}$ chẩn đoán gãy loại $A 2.1$ trên XQ được chuyển sang loại A2.2 trên phim CLVT, lý do không phát hiện được các mảnh gãy mấu chuyển trên phim XQ nhưng trên phim CLVT thì phát hiện được. Sự phù hợp về chẩn đoán giữa $X Q$ và $C L V T$ là $58 / 101$ trường hợp $(57,42 \%)$ và hệ số $K=0,466$.

\section{KẾT LUẬN}

Phân loại gãy liên mấu chuyển dựa trên phim $X$ quang có sự hạn chế về độ chính xác. Hình ảnh chụp CLVT có dựng hình $3 \mathrm{D}$ đã được chứng minhlà chính xác cao hơn do phát hiện đây đủ hơn về vị trí, hình thái các đường gãy và số lượng mảnh gãy. Nhiều tổn thương giải phẫu đã không được phát hiện trên phim XQ qui ước, nhưng nhờ có chụp cắt lớp có dựng hình $3 \mathrm{D}$ đã xác định được, đặc biệt là các trường hợp gãy 3 phần có tổn thương thành ngoài và có đường gãy phía sau liên quan đến mảnh chéo lớn bao gồm cả mấu chuyển bé.

\section{TÀI LIÊUU THAM KHẢO}

1. Wada K., Rui A., Hiroshi M.et al. (2019)A novel three-dimensional classification system for intertrochanteric fractures based oncomputed tomography findings. The Journal of Medical Investigation, 2019. 66: p. 362-366.

2. Etsuo Sh., Shimpei K., Yu S. et al. (2017) 
Proposal of new classification of femoral trochanteric fracture by three-dimensional computed tomography and relationship to usual plain X-ray classification. Journal of Orthopaedic Surgery 2017. 25(1): p. 1-5.

3. RussellT.A.,(2015). Intertrochanteric Fractures. Rockwood \& Green's Fractures in Adults. 8th Edition. Vol. 2., Lippincott Williams \& Wilkins.

4. Ming Li(2019). Three-dimensional mapping of intertrochanteric fracture lines. Chinese Medical Journal, Vol132(21), p: 2524-2533.

5. El Sayed Abdullah, Mina E. S.(2021). The role of preoperative computed tomography in surgical planning of intertrochanteric femur fractures fixation. Int J Res Orthop. Mar;7(2), p:211-218.

6. Futamura K, Baba T, Homma Y, et al (2016). New classification focusing on the relationship between the attachment of the iliofemoral ligament and the course of the fracture line for intertrochanteric fractures. Injury $47(8)$ : 1685 1691,2016

7. Cho Y.C., Lee P. Y., Lee Ch. H et al (2018). Three-dimensional CT improves the reproducibility of stability evaluation for intertrochanteric fractures. Journal of Orthopaedic Surgery 2018 Volume $10 \bullet$ Number 3,August.

\section{THỰC TRANG CÁC VẤN ĐỀ SỨC KHOẺ CÓ CAN THIÊP PHƯC HỒI CHỨC NĂNG TẠI MộT SỐ BÊ̂NH VIÊ̂N TUYẾN TỈNH VÀ TUYỂN HUYỆN Ở CÁC VÙNG SINH THÁI VIÊTT NAM}

Đoàn Quốc Hưng*, Lê Minh Giang*, Phạm Văn Minh*, Nguyễn Thị Kim Liên*, Nguyễn Ngọc Long*, Trần Thị Hảo*, Chu Thị Quỳnh Tho*, Ngân Thị Hồng Anh*, Phạm Phương Mai*, Đào Vũ Hoàng*, Nguyễn Thị Thu Hà*, Hoàng Thị Hải Vân*

\section{TÓM TẮT}

Nghiên cứu nhẳm mô tả thực trạng các vấn đề sức khoẻ có can thiệp phục hồi chức nằng (PHCN) tại các bênh viện tuyến tỉnh và tuyến huyện tại 7 tỉnh đạ diên cho 7 vùng sinh thái trên cả nước. Kết quả cho thấy, tại 26 bệnh viện nghiên cứu, tỷ lệ các vấn đề sức khoẻ có can thiệp PHCN ở nhóm khuyết tật về vận đông có tổng số ca được báo cáo nhiêu nhất (khoảng $70 \%)$, đặc biệt là các vấn đề về cơ xương khớp là 16,705 ca, các vấn đề về côt sống là 11,655 catheo thống kê trong năm 2020, chiếm tỷ lệ thấp nhất là các vấn đề sức khoẻ có can thiêp PHCN ở nhóm giảm cảm giác với 1,539 ca $(2,6 \%)$ năm 2020.Mô hình bệnh tật các vấn đề sức khoé có can thiệp PHCN ngày càng thay đổi và đa dạng hơn qua các năm, trong đó các vấn đề về cơ xương khớp và tự kỉ ở trẻ em có xu hướng ngày càng giảm,các vẫn đề về cột sống và tai biến mach máu não ngày càng tăng. Vì vây, việc hiểu rõ mô hình các vấn đề sức khoẻ có can thiệp PHCN là cần thiết để nâng cao chất lượng khám chữa bệnh, can thiệpPHCN cũng như định hướng đào tạo chuyên ngành PHCN trong tương lai.

Từ khóa: Phục hồi chức năng, bệnh viện tuyến tỉnh, bệnh viện tuyến huyện.

\section{SUMMARY \\ THE SITUATION OF REHABILITATION DISEASES AT MULTILEVEL OF HOSPITALS ACCORDING TO ECOLOGICAL AREAS IN VIETNAM}

\section{*Trường Đại học Y Hà Nôi}

Chịu trách nhiếm chính: Hoàng Thị Hải Vân Email: hoangthihaivan@hmu.edu.vn Ngày nhân bài: 7/4/2021

Ngày phản biên khoa họ: 29/4/2021 Ngày duyệt bài: 19/5/2021
The study aims to describe the situation of rehabilitation diseases of city/province general hospitals, district general hospitals and specialized rehabilitation hospitals. The results showed that among 26 hospitals were collected, the proportion of rehabilitation diseases in the mobility disability group with the most total number of reported cases out of the total number of diseases requiring rehabilitation (about 70\%), especially musculoskeletal diseases with 16705 cases, spinal diseases with 11655 cases in 2020. In addition, rehabilitation diseases in the sensory reduction group were the lowest with 1539 cases $(2.6 \%)$ in 2020 . The rehabilitation diseases pattern is increasingly changing changes and diversity over the years. The musculoskeletal diseases and autism in children are decreasing, while diseases of the spine and stroke are increasing. Therefore, understanding the rehabilitation diseases model is necessary to improve the quality of rehabilitation examination and treatment in the future.

Keywords: Rehabilitation, provincial hosital, district hospital

\section{I. ĐẶT VẤN ĐỀ}

Khuyết tật là tình trạng khiếm khuyết một hoăc nhiêu bộ phận cơ thể hoặc bị suy giảm chức năng được biểu hiện dưới dạng tật khiến cho lao động, sinh hoạt, học tâp gặp khó khăn[1]. Năm 2017, theo như phân tích toàn cầu, có tới 291,2 triệu $(11,2 \%)$ trong số 2,6 tỷ trẻ em và thanh thiếu niên được ước tính trên thế giới có ít nhất 1 trong 4 dạng khuyết tật cụ thể. Tỷ lệ mắc các dạng khuyết tật này tăng theo độ tuổi từ 6,1\% ở trẻ em <1 tuổi đến $13,9 \%$ ở trẻ vị thành niên từ 15 đến 19 tuổi, chủ yếu ở ở các nước có thu nhập thấp và trung bình 